logically similar appearances seen in polyarteritis nodosa, Goodpasture's syndrome, Henoch-Schönlein syndrome, and idiopathic focal nephritis associated with mesangial $\operatorname{IgA} / \operatorname{IgG}$ deposits (Berger, 1969; Berger et al., 1971). Serial determinations of serum complement were valuable in assessing activity of the immune-complex disease and its response to therapy, and in one of our patients the fall in plasma C3 concentration was helpful in diagnosing relapse.

Even before the advent of antibiotics renal failure in subacute infective endocarditis was unusual (Baehr, 1921). It was, however, a striking feature in this group of patients, four of whom needed peritoneal dialysis. Two of these patients recovered good renal function, one died of cardiac failure shortly after admission, and the fourth patient, with extensive glomerular destruction, had irreversible renal failure. In one of the patients who recovered there was also clinical and histological evidence of acute tubular necrosis but in the remaining patients renal failure was due solely to glomerulonephritis. The striking improvement in renal function after eradication of infection emphasizes the importance of persistence of antigen in the progression of nephritis and the degree of recovery that is possible unless widespread glomerular scarring has already occurred. The importance of early diagnosis and effective treatment is evident.

We should like to thank Professor J. P. Shillingford and Professor J. F. Goodwin for allowing us to study their cases and Miss Jane Fallows and Dr. Gwyn Williams for help with studies of the complement system.

\section{References}

Baehr, G. (1921). Archives of Internal Medicine, 27, 262.

Berger, J. (1969). Transplant Proceedings, 1, 939.

Berger, J., Yaneva, H., and Hinglais, N. (1971). In Advances in Nephrology, ed. J. Hamburger, J. Crosnier and M. H. Maxwell, Chicago, Year Book Medical Publishers.

Berman, L., and Myers, A. M. (1972). South African Medical fournal, 46, 850 .

Burch, G. E., and Colcolough, H. L. (1969). Annals of Internal Medicine, $71,963$.

Evans, D. J., et al., (1973). British Medical fournal, 3, 326

Feltkamp, T. E. W., and Boode, J. H. (1970). Fournal of Clinical Pathology, 23, 629.

Germuth, F. G., Senterfit, L. B., and Dressman, G. R. (1972). Fohns Hopkins Medical fournal, 130, 344.

Germuth, F. G., and Rodriguez, E. (1973). Immunopathology of the Renal Glomerulus, Boston, Little, Brown \& Co.

Gutman, R. A., Striker, G. E., Gilliland, B. C., and Cutler, R. E. (1972). Medicine, 51, 1.

Heptinstall, R. H. (1966). Pathology of the Kidney, p. 330. London, Churchill. Levy, R. L., and Hong, R. (1973). American fournal of Medicine, 54, 645.

Libman, E., and Freiberg, L. K. (1948). Sub-acute Bacterial Endocarditis. 2nd edn., p. 364. New York, Oxford Medical Publications.

McIntosh, R. M., et al., (1971). Quarterly fournal of Medicine, 40, 385.

Macanovic, M., Evans, D. J., and Peters, D. K. (1972). Lancet, 2, 207.

Meyer, K. F., Eddie, B., and Schachter, J. (1969). In Diagnostic Procedures for Viral and Ricketsial Infections, ed. E. H. Lenette and N. J. Schmidt, 4th edn., New York, American Public Health Association Incorporated. Morel-Maroger, L., Sraer, J. D., Herreman, G., and Godeau, P. (1972). Archives of Pathology, 94, 205.

Nairn, R. C. (1969). Fluorescent Protein Tracing, 3rd edn., p. 303. Edinburgh, Livingstone.

Tu, W. H., Shearn, M. A., and Lee, J. C. (1969). Annals of Internal Medi-

Williams, D. G., Charlesworth, J. A., Lachmann, P. J., and Peters, D. K. (1973). Lancet, 1, 447.

Wilson, C. B., and Dixon, F. J. (1971). Fournal of Experimental Medicine, 134, $7 \mathrm{~S}$.

\title{
Response to Propranolol and Diazepam in Somatic and Psychic Anxiety
}

\author{
P. J. TYRER, M. H. LADER
}

British Medical fournal, 1974, 2, 14-16

\section{Summary}

A total of 12 chronically anxious psychiatric outpatients were treated with racemic propranolol (Inderal), diazepam (Valium), and placebo for one week each, using a balanced cross-over experimental design. Six patients had predominantly somatic anxiety, complaining mostly of bodily symptoms, and six had mainly psychic anxiety, complaining primarily of psychological symptoms. Clinical ratings of anxiety were made by patient and psychiatrist after each treatment. Though diazepam was in general more effective than propranolol or placebo in relieving anxiety, propranolol was more effective than placebo in patients with somatic anxiety but not in those with psychic anxiety. We suggest that propranolol should be reserved for patients whose anxiety symptoms are mainly somatic.

Bethlem Royal and Maudsley Hospitals, London S.E.5

P. J. TYRER, M.R.C.P., M.R.C.PSYCH., M.R.C. Clinical Research Fellow and Honorary Senior Registrar (Present address: Department of Psychiatry, South Block, Southampton General Hospital, Southampton)

Institute of Psychiatry, De Crespigny Park, Denmark Hill, London SE5 5AF

M. H. LADER, M.D., M.R.C.PSYCH., Reader in Clinical Psychopharmacology
Introduction

Granville-Grossman and Turner (1966) were the first to suggest that beta-adrenoceptor blockade might be effective in the treatment of pathological anxiety. Some more recent reports suppont this view (Wheatley, 1969; Conway, 1971; Bonn et al., 1972; McMillin, 1973). Nevertheless, neurotic anxiety is not commonly treated with beta-blocking drugs and there are no clear indications for their use. Granville-Grossman and Turner (1966) found that only autonomically mediated symptoms were significantly improved by propranolol; anxiety, tension, and irritability were not. In view of the known peripheral effects of beta-adrenoceptor blockade these findings were not unexpected, but to what extent a reduction in autonomic symptoms creates clinical improvement is debatable (Ramsay et al., 1973). Anxious patients vary greatly in their emphasis on the somatic or the psychological aspeots of their anxiety. We took this into account in planning the present investigation of the effects of propranolol compared with those of diazepam and placebo in anxious patients.

\section{Patients and Methods}

Outpatients attending the Maudsley Hospital with a primary diagnosis of chronic anxiety state (continuous symptoms for at least four months) were considered for the trial. Patients with cardiac disease and asthma were excluded. Out of 15 patients selected one group suffered mainly from somatic anxiety, placing most emphasis on bodily symptoms, and another group 
suffered mainly from psychic anxiety, dismissing their somatic symptoms as secondary features. All had had previous psychiatric outpatient treatment and one had been an inpatient. Each patient was given three lots of white capsules of identical appearance, containing respectively racemic propranolol (40 $\mathrm{mg}$ ), diazepam ( $2 \mathrm{mg}$ ), and placebo, to be taken for one week each over a period of three weeks. The dosage regimen was flexible and a range of three to nine capsules daily in three divided doses was allowed. Order effects of treatment were allowed for by using a Latin square experimental design. A period of one week's treatment with each drug was thought to be enough to show clinical response since their pharmacological effects are rapid in onset. Both propranolol (Shand et al., 1970) and diazepam (Van der Kleijn, 1971) have short half-lives and are rapidly excreted, so contamination of clinical response by persistence of the previously prescribed drug was unlikely. The mean daily dose taken was calculated from the number of unused capsules returned after each treatment.

The degree of anxiety was rated in each patient before the trial and after each treatment by a modification of the Hamilton rating scale (Hamilton, 1959) in which $100-\mathrm{mm}$ linear scales were used instead of categorical ones (Lader and Marks, 1971). After all clinical ratings were completed a number of physiological measurements were recorded; the results of these will be published elsewhere. When each patient had completed all three treatments he was asked to rank them in order of efficacy. If the improvement from any of the treatments was ranked as substantial it was continued, though the drug concerned was not known by the investigator until the code was broken when the last patient had completed the trial.

\section{Results}

Three out of the 15 patients who entered the trial did not complete treatment-one because his symptoms worsened, and the two others because they continued previous medication despite instructions to the contrary. Six patients in each of the two groups completed treatment. All but four showed a clear preference for diazepam (table). When the results for the somatic and psychic anxiety groups are presented together propranolol appears to be no better than placebo, but when the results for the two groups are presented separately a differential response is shown. Propranolol was preferred to placebo in the somatic group but not in the psychic one.

\section{Patients' Treatment Preference}

\begin{tabular}{|c|c|c|c|c|}
\hline \multirow{2}{*}{ Group } & \multirow{2}{*}{ Case No. } & \multicolumn{3}{|c|}{ Rank Order (With Correction for Tied Ranks) } \\
\hline & & Diazepam & Propranolol & Placebo \\
\hline Somatic & $\begin{array}{l}1 \\
2 \\
3 \\
4 \\
5 \\
6\end{array}$ & $\begin{array}{l}1 \\
1 \\
2 \\
2 \\
1 \\
1 \cdot 5\end{array}$ & $\begin{array}{l}2 \\
2 \\
2 \\
1 \\
2 \\
1 \cdot 5\end{array}$ & $\begin{array}{l}3 \\
3 \\
2 \\
3 \\
3 \\
3\end{array}$ \\
\hline Psychic & $\begin{array}{l}1 \\
2 \\
3 \\
4 \\
5 \\
6\end{array}$ & $\begin{array}{l}1 \\
1 \\
1 \\
1 \\
1.5 \\
1\end{array}$ & $\begin{array}{l}3 \\
2 \\
3 \\
3 \\
3 \\
3\end{array}$ & $\begin{array}{l}2 \\
3 \\
2 \\
2 \\
1 \cdot 5 \\
2\end{array}$ \\
\hline
\end{tabular}

Kendall's coefficient of concordance $(w)$ (Siegel, 1956) $=0.51 ; P<0.01$.

Statistical testing of the Hamilton ratings was carried out by a split-plot analysis of variance. Significant $F$ ratios for drug and drug times group interaction were subjected to Tukey's test (Winer, 1962) to find the critical difference between individual drug means. The mean Hamilton rating of anxiety was significantly lower in both groups for diazepam $(F=10.2$; D.F. 2,$16 ; P<0.01)$ compared with the other agents. Again there was a differential response to propranolol in the two groups of patients; propranolol was almost as effective in the somatically-anxious patients as was diazepam, but substantially less so in the psychically anxious ones (fig.) $(F=5.0$; D.F. 2, 16; $P<0.05)$. Order effects were insignificant. In some studies with anxious patients an initial improvement was shown whatever the treatment (Roberts and Hamilton, 1958; Granville-Grossman and Turner, 1966).

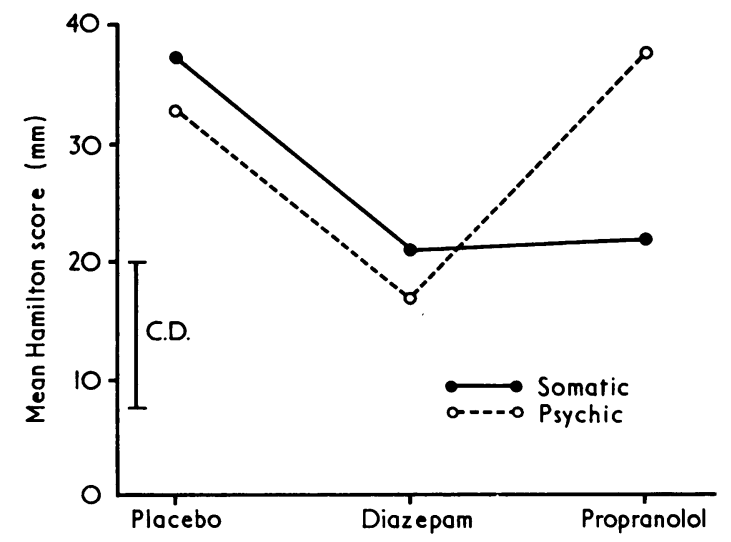

Hamilton rating scale scores: differential group effects. Pairs of means further apart than critical difference (C.D.) are significant at $5 \%$ level.

The absence of such a non-specific response in our patients can be explained by the chronicity of their complaints.

The means of the numbers of capsules taken daily were placebo, 3.1; diazepam, 4.8 (9.6 $\mathrm{mg})$; propranolol, 3.0 (120 mg).

\section{FOLLOW-UP}

The patients were followed-up for a least six months after completing the trial. At six months two patients were still taking propranolol in small doses, five were taking diazepam (or chlordiazepoxide), and two were taking both. The nature of their symptoms did not alter appreciably.

\section{Discussion}

The results indicate that diazepam is generally more effective than propranolol (and placebo) in the treatment of morbid anxiety. Though the patients were a highly-selected sample whose anxiety was more persistent than usual there is no reason to believe that it was qualitatively different from milder forms. Neventheless, propranolol does have important clinical effects in somatically anxious patients. Its efficacy in this group is comparable to diazepam and its use is preferable because it rarely produces sedation, is very safe, and not prone to abuse. It must be emphasized that the patients who responded relatively well to propranolol did not necessarily have more somatic symptoms than those in the psychic anxiety group, but they complained of them primarily and tended to deny the psychological aspects of their condition. Since somatic symptoms become more severe as anxiety increases it was impontant to ensure that the difference between the groups was not based on the severity of the conditions. A one-way analysis of variance on the patients' scores before treatment showed no significant difference between the two groups, so this possibility was unlikely.

It is interesting that most patients with psychic anxiety preferred placebo to propranolol. Lader and Tyrer (1972) found 
that propranolol in a single dose of $120 \mathrm{mg}$ caused normal people to feel significantly more troubled than when on placebo and that these feelings occurred in the absence of sedation. Perhaps alteration of bodily sensations may be perceived as unpleasant by those who do not complain of somatic anxiety. The therapeutic indications for propranolol in pathological anxiety seem to be confined to patients who do not complain of anxiety even though their somatic symptoms are clearly due to anxiety. Symptoms caused by tachycardia and tremor, both of which are significantly lessened by betaadrenoceptor blockade in anxious patients (Turner et al., 1965; Marsden et al., 1968; Tyrer and Lader, 1973), are especially likely to be helped. In such patients the removal of the symptom is enough to bring considerable clinical relief. This supports the view that bodily symptoms may be more fundamental in morbid emotion than is usually thought (Tyrer, 1973), and is consistent with the long-standing clinical impression that patients with somatic complaints are best treated by somatic therapy (Misch, 1935).

The results of our study are also consistent with previous reports of the effectiveness of beta-receptor blockade in other conditions. It could be argued that the primary complaint in "hypendynamic beta-adrenergic circulatory state" (Frohlich et al., 1966), "nervous heant complaint" (Nordenfelt et al., 1968), "hyperventilation syndrome" (Suzman, 1968), and "vasoregulatory asthenia" (Holmgren et al., 1957) is that of anxiety presenting in the guise of somatic malfunotion. In all these conditions beta-receptor blockade is beneficial (Marsden, 1971). If the speotrum of somatic anxiety is extended to include such functional disorders the type of patient suitable for treatment with beta-blocking agents is better defined. It remains to be seen whether there are differences in response between individual beta-blocking agents but from our knowledge of their clinical effects in other conditions this seems unlikely, provided they are given in equipotent dosage (Thadani et al., 1973). The clinical presentation of anxiety is so varied and the pharmacological differences between the beta-blocking drugs so small by comparison that it is the selection of the right patient for treatment rather than choice of drug which is likely to be critical for success.

We are grateful to Dr. P. Bayliss of I.C.I. Pharmaceuticals Division for supplying the capsules of propranolol, diazepam, and placebo, and to Vivien Maclean for co-ordinating their allocation. This work was supported by the Medical Research Council.

Requests for reprints should be sent to Dr. Tyrer.

\section{References}

Bonn, J. A., Turner, P., and Hicks, D. C. (1972). Lancet, 1, 814. Conway, M. (1971). Practitioner, 206, 795.

Frohlich, E. D., Dunstan, H. P., and Page, I. H. (1966). Archives of Internal Medicine, $117,614$.

Granville-Grossman, K. L., and Turner, P. (1966). Lancet, 1, 788.

Hamilton, M. (1959). British fournal of Medical Psychology, 32, 50

Holmgren, A., et al. (1957). Acta Medica Scandinavica, 158, 437.

Lader, M. H., and Marks, I. M. (1971). Clinical Anxiety, p. 99. London, Heinemann Lader, M. H., and Tyrer, P. J. (1972). British fournal of Pharmacology, 45,

McMillin, W. P. (1973). Lancet, 1, 1193.

Marsden, C. D., Gimlette, T. M. D., McAllister, R. G., Owen, D. A. L., and Miller, T. N. (1968). Acta Endocrinologica (Kobenhavn), 57, 353.

Marsden, C. W. (1971). Postgraduate Medical fournal, Suppl. 47, 100.

Misch, W. (1935). Fournal of Mental Science, 81, 389.

Nordenfelt, I., Persson, S., and Redfors, A. (1968). Acta Medica Scandinavica, 184, 465.

Ramsay, I., Greer, S., and Bagley, C. (1973). British fournal of Psychiatry, $122,555$.

Roberts, J. M., and Hamilton, M. (1958). Fournal of Mental Science, 104, 1052 .

Shand, D. G., Nuckolls, E. M., and Oates, J. A. (1970). Clinical Pharmacology and Therapeutics, 11, 112.

Siegel, S. (1956). Non-parametric Statistics for the Behavioral Sciences, p. 229. New York, McGraw-Hill.

Suzman, M. M. (1968). Annals of Internal Medicine, 68, 1194.

Thadani, U., et al. (1973). British Medical fournal, $1,138$.

Turner, P., Granville-Grossman, K. L., and Smart, J. V. (1965). Lancet, 2, 1316.

Tyrer, P. J. (1973). Lancet, 1, 915.

Tyrer, P. J., and Lader, M. H. (1973). Clinical Pharmacology and Therapeutics, 14, 418 .

Van der Kleijn, E. (1971). Annals of the New York Academy of Sciences, 179,

Wheatley, D. (1969). British Fournal of Psychiatry, 115, 1411.

Winer, B. J. (1962). Statistical Principles in Experimental Design. New York, McGraw-Hill.

\title{
Long-term Chelation Therapy in Thalassaemia Major: Effect on Liver Iron Concentration, Liver Histology, and Clinical Progress
}

\author{
MICHAEL BARRY, DAVID M. FLYNN, ELIZABETH A. LETSKY, R. A. RISDON
}

British Medical fournal, 1974, 2, 16-20

\section{Summary}

A prospective trial of continuous chelation therapy in children with homozygous thalassaemia on a high transfusion

Department of Medicine, Royal Free Hospital, London WC1X 8LF MICHAEL BARRY, M.D., M.R.C.P., Senior Medical Registrar

Hospital for Sick Children, Great Ormond Street, London W.C.1

DAVID M. FLYNN, M.D., M.R.C.P., Honorary Consultant Physician (Present appointment: Consultant Paediatrician, Royal Free Hospital, London.)

Department of Haematology, Institute of Child Health, London W.C.1 ELIZABETH A. LETSKY, M.B., M.R.C.PATH., Lecturer in Haematology

Department of Morbid Anatomy, Institute of Child Health, London W.C.1

R. A. RISDON, M.D., M.R.C.PATH., Senior Lecturer in Morbid Anatomy regimen was started in April 1966. The effect of treatment on iron concentration in the liver and on hepatic histology was examined in 49 biopsy specimens obtained from nine chelator-treated patients and nine control patients between April 1966 and April 1973.

Chelation therapy was associated with a significant reduction in liver iron concentration, and by the end of the trial the values for the two groups showed no overlap. A similar difference was seen in the amount of hepatic fibrosis, which showed little or no change in the chelator-treated patients but was progressive in the controls.

No major clinical differences were seen, probably because both groups included several older children who were heavily loaded with iron at the start of the trial. Among the younger patients, however, puberty was delayed in four of five controls but in only one of four chelator-treated children. Prepubertal growth rate was significantly greater in the chelatortreated patients than in the controls. 